\section{Stepanov Saša ${ }^{1}$}

University Business Academy in Novi Sad

MEF Faculty of Applied Management,

Economy and Finance, Belgrade
SCIENTIFIC REVIEW ARTICLE doi:10.5937/ekonomika1701083S

Received January, 31, 2017 Accepted: February, 28, 2017

\title{
Stepanov Nemanja
}

University of Belgrade, Faculty of Political Sciences in Belgrade

\section{Vukotić Nataša}

University Business Academy in Novi Sad

MEF Faculty of Applied Management, Economy and Finance, Belgrade

\section{QUALITY MANAGEMENT OF CATERING SERVICES}

\begin{abstract}
Today's quality, in terms of high competition and an increasingly growing demands of consumers one of the key factors for the survival of business systems on the market. From the point of customer service quality in the tourism industry, and its expectations are growing every day and more.

By providing continuous and complete quality of service, set the preconditions for achieving customer satisfaction and in this sense by providing the desired quality for them and their satisfaction achieved a number of competitive advantages. The system TQM - Total Quality Management (TQM) is a philosophy that the tourism developed countries finds its application and includes a number of activities to be undertaken in quality assurance. The long-term source of revenue for the company are satisfied customers, both positive propaganda which they perform, thus affecting the new, potential guests, as well as restoring and repeated visits.
\end{abstract}

Key words: service quality standard, customer satisfaction, loyalty

Jel classification: M54, Z3, Z32

\section{УПРАВЉАЫЕ КВАЛИТЕТОМ УГОСТИТЕЉСКИХ УСЛУГА}

\begin{abstract}
Апстракт
Данас је квалитет , у условима велике конкуренције и све већег раста захтева потрошача један од кључних фактора опстанка пословних система на тржишту. Посматрано са аспекта потрошача квалитет услуге у туризму, односно његових очекивања су сваким даном све већа и већа.

Обезбеђиваьем континуираног и потпуног квалитета услуге, постављају се предуслови за постизаье сатисфакције госта па се у том смислу обезбеђивањем жељеног квалитета за юих и юиховом сатисфакиијом постижу бројне конкурентске предности. Систем TQM - Тотал Quality Манагемент (управљање
\end{abstract}

\footnotetext{
${ }^{1}$ sasa.stepanov@gmail.com
} 
тоталним квалитетом) представља филозофију која у туристички развијеним земьама налази своју примену и подразумева читав низ активности које је потребно предузимати у обезбеђивану квалитета. Дугорочни извор прихода за предузећа представљају задовољни потрочачи, како позитивном пропагандом коју врме, чиме утичу на нове,потенцијалне госте, тако и враћањем и поновљеним посетама .

Кључне речи: квалитет услуге, стандард, задовољство потрочача, лојалност

\section{Introduction}

For centuries mankind has evolved to meet the needs that are accompanied by their original communities until today. The essence of human civilization and existence consisted of solutions that allow better quality of life. Quality time is crystallized as a concept without which, from ancient times to the modern era, we can not imagine the progress of humanity and the life of every individual.

Quality as an issue is present in all spheres of society, including entrepreneurship, and the modern understanding of management. Many contemporaries from different scientific disciplines feel that without serious approach to the problem of quality of developing countries and therefore the organization is unsustainable, because they believe that the new millennium will be dedicated to the concept of quality. Globalization thanks to intensifying social relations eventually crosses national borders and boosting competitiveness. Domestic markets are no longer closed but the market turned so that companies their services and products can freely provide consumers around the world. Similarly the organization will lose control over what they can not produce competitively. Organizations that are constantly monitored and improved our business practices and performance have had a chance to survive in the market and profitable business, and depending on the aspiration to increase its share of the market (Brzaković, Radulović, 2014).

In such conditions, the business game 'quality becomes a major and central obligations and aspects of any organization that is considering the market and its objectives directed towards the long-term success. The quality of products and services competitive influence, all with the only real aim and satisfaction of consumers.

In everyday language, often use the term "quality". The roots of this expression is found in the Latin word "qualis" - excellent, good quality, which is good for use, which is characterized by good qualities. The association of the term is always something that is well worth, meets expectations, deserves attention.

Depending on the authors in the literature appear different approaches to defining the concept of quality: Jurana (Joseph, 1988), Kotler (Kotler, Keller, 2006), Hellriegel (Hellriegel, Slocum, 2008), but common to all is that quality is a key element of the value of services on the basis of which ensures the positioning of the enterprise in the market, its larger market share which requires mutual satisfaction to customers and staff

International Organization for Standardization (ISO) with its definition in 2000 on the "quality" refers to the totality of characteristics of a product or services that meet the needs and expectations that are pre-determined and its precise interpretation of the 2005 'level to 
which a set of inherent product characteristics meet the requirements. "Under the features are considered traits on the basis of which a distinction is made in the assessment of quality.

The quality of service is at the present time is crucial, and the service quality is of great importance for positioning and market survival.

The quality of products and services is becoming more critical market factor that separates business system - the company of others. By meeting the market preconditions that imply the existence of developed market relations, willingness to adapt Manufacturer customer requirements, constant volatility of demand and supply and the obligation of companies to permanent sustainability in quality Despite achieving the desired quality, continuous and maintained it is necessary to constantly conduct research on the needs of consumers (customer - guest) for a certain quality.

Quality of service is the primary means of enterprises to continuously attract customers, retaining and constant quality improvement. He is a permanent gap between consumer expectations and what he really gets that experience. Quality of service includes not only the product supplied already includes evaluating the delivery process.

Quality of service is therefore the level of satisfaction of user needs and requirements, and compliance with the growing demands and expectations.

Quality of service has two main dimensions:

- Technical and

- Functional.

Under the technical quality of the result of the process involves generating services and it can be significantly more objectively assess or measure as opposed to a functional that represents the attitude of subjective observations and refers to how consumers consume services.

Taking into account the importance of quality in relation to the quality of services - customer satisfaction resi must determine shortcomings and mistakes (if any) in order to constantly improve quality. Continuity of quality and constant improvement of a number of innovation lead to the desired quality. The cost of introducing quality systems represent an investment for the future of each company.

Quality catering services that consumers expect a standard by which to assess the quality of the service provided, including the need for and commitment to quality of food and drink is defined on the basis of objective and precisely defined data. If take for basis and reason for going to a restaurant and eating food that gastronomic product generated by different methods of processing various types of food products consisting of several food products integrated The specific properties that unlike other products have food and drinks and have the properties to meet the physiological needs of the human senses have to meet:

1. Technical - technological aspect

2. Microbiological second aspect

3. Health - a safety aspect

4. Nutritional fourth aspect

5. Sensory aspect

- Technical - technological aspect includes properties of raw materials, methods and procedures in the preparation, norms and ways of servicing.

- Area of microbiology aspect indicates to you in the food and drink is greater than the permitted number of micro-organism and the absence pathogenic organism. 
- Health - a safety aspect of contamination of food with chemicals (heavy metals, pesticides )

- Nutritional aspect involves the representation of nutrients and the building materials necessary for the normal functioning of a human organism.

- Sensory aspect is evaluating the characteristics of the food with the sense of (one or more) in order to give proper objective results.

\section{Total quality management - TQM}

In order to meet the needs and expectations of consumers quality management is constantly evolving in line with the problems in the market. The quality management system is developed through phases.

1. Inspection sacrificing I \& $\mathrm{T}$

2. Quality control QC

3. Providing quality QA

4. Full quality control TQQ

5. Management of Total Quality TQM

TQM - as the latest concept of quality management implies the involvement of all actors involved in the creation of products and services, thereby helping level of quality.

In order to apply the concept of TQM is necessary to fulfill certain conditions: (Ljubojević, 2004)

- Greater autonomy and more authority employees

- Engagement - loyalty management

- Quality Corporation

- Statement of the Mission

- Comparative analysis in order to best practices

- Education and training

- The system of compensation

- Communication

- Leadership

- Business Ethics

The main aspect to improve service quality and to decrease the cost of getting steadily in importance. The very fact of increasing competition in the market, contributing to TQM is gaining in importance of applying the concept.. This concept should be imperative for any service company because its application easier to meet and exceed the needs and expectations of consumers.

Under standard means "publicly available document, established by consensus and adopted by a recognized body, in which the general and reusable establishes the rules, requirements, characteristics, instructions, recommendations or guidelines for activities or their results, in order to achieve optimal level of regulation in particular authorities in relation to actual or potential problems, "the standardization of the" set of coordinated activities on the adoption of standards and related documents "

Striving to enable the continuous provision of quality services or products resulting standards. By defining the requirements and characteristics that must be met in order to ensure the same quality of each customer are set standards. 
The application of standards in the economy, and therefore in the hospitality industry, has great significance, both for consumers and for entrepreneurs who thus simplify and accelerate the process of business activities, reduce costs and increase profits, enhance the quality of work atmosphere and the service provided.

Their implementation is a complex process consisting of several stages:

- Prescribing standards,

- Application of standards,

- Control of the application of standards,

- Improving standards.

- Education and training of employees,

- Standards are made in the context of the enterprise, the level of professional associations and within the state itself and the division can be made to:

- The external standard and

- Internal Standard

States in the form of laws, regulations and other documents regulating the external standard, and they are required in the operations of hotels, restaurants, or the same facilities. External standards can be established at the international level, and commonly encountered in the hospitality sector, in hotel chains or fast food restaurants.

Internal standards in restaurant can occur in two forms:

- Formal and

- informal

and they are reflected in the written and oral rules on how to provide services. Internal standards are more rigorous than the standards set by the state as is the case in the hotel because hotels want to provide the same level of quality to their guests worldwide, while respecting internal standards even though, according to the regulations of each state could operate with smaller investments necessary to implement the standard.

Common to the implementation of standards at the restaurant whether it is on the external or internal standards is:

- standard for the construction of a catering facility,

- the standard of furnishing and equipping the service and manufacturing work,

- the standard of health security landscape of food,

- standard on quality management,

- Standard horizontal and vertical communication,

- standards for dealing with guests

- standards to protect the health of employees and safety at work,

- standards relating to human resources,

- standard for the application of information technology and,

- the standard of environmental protection,

International Organization for Standardization ISO (the International Organization for Standardization) in 1987 published the first international standard of quality. The standards of this organization were created on the basis of international experience in different areas of business and thus provide systematic quality improvement in all companies to implement them in business. In accordance with market trends and scientific achievements, standards are subject to change and is periodically changed and amended. 
Acceptance of these standards also means a simpler comparison of the experiences of companies around the world and find a solution for any shortcomings in the work. The absence of barriers and differences in international business, a special contribution for the establishment, maintenance and improvement of quality in the provision of catering services to the global market.

Here are some of the most applied international standards in the hospitality sector.

Standards belonging to the ISO 9000 and relate to quality management:

ISO 9000 gives definitions of basic terms, standardization of terms,

ISO 9001 defines the requirements necessary for a quality management system,

ISO 9004, a more efficient and effective quality management,

ISO 9011, guidelines for internal and external control of the quality management system.

ISO 14000, the management of environmental protection,

ISO 22000, the management of food safety,

ISO 26000, the management of social responsibility,

OHSAS 18000, the management of protection and safety at work,

HACCP, Hazard Analysis and Critical Control Point,

Probably the most important part of this standard is HACCP (Hazard Analysis and Critical Control Points). HACCP system practically forms the basis of the ISO 22000 and next to it a certain basis of form and mention the standards of ISO 9000 and ISO 14000 HACCP is a system for the identification, assessment and control of hazards of harmful effects on the health safety of food. The system includes the analysis and control of biological, chemical and physical hazards from raw materials to the end product that serves the consumer. Benefits application of the HACCP system is reflected in the following: (Popov - Raljić, Blešić, 2012)

- Reduction of disease outbreaks caused by food

- Supply of population health safe food,

- The ability to meet the requirements of legislation and more effective inspection,

- The possibility of more effective and efficient operation food companies,

- Increasing competitiveness in the global market,

- Removing barriers to international trade,

- The possibility of an efficient introduction of new technologies and products,

- Increase profits,

- Contribution to better organization of work,

- Better control of the efficiency of individual workers on the job,

- Gaining the trust of consumers.

In accordance with the legal provisions of the Republic of Serbia, all the economic operators who are in the chain of imports, storage, production, distribution of food raw materials or products, and establishments engaged in further processing of food (prepared dishes) and service, are required to implement HACCP system (Popov - Raljić, Blešić, 2013). A good feature of this system is the possibility of implementation in all establishments that provide food and beverage services, regardless of type, type or size.

It is especially important to point out that in the world a great deal about the implementation of standards relating to food, and refer to the standards: 
- HALAL-standard confirming that the food in accordance with Islamic rules and customs that are allowed for consumption and

- KOSHER-standards that confirm that food products meet the requirements prescribed by Jewish law can consume them members of the Jewish religious community.

The application of these standards is particularly important for restaurants that are located in the multi-ethnic communities, and on the basis of which they can gain a competitive advantage and recognition among consumers. The special quality is achieved by obtaining a certificate from the competent authorities, which guarantees the company's operations according to the principles of standards and quality systems.

\section{Management welcomes guests in restaurants}

To manage certain activities, it is necessary at the outset to have a clear idea of which direction we want to go, that is what we want to achieve in the market. On the basis of the target segment and a clear market orientation is necessary to ascertain the wishes, needs and expectations of consumers on the basis of which further define the level of quality to be achieved due to its satisfaction. Business catering companies see consumers as the main target group of which largely depends. Their needs and desires are at the center of marketing research, or in the center of overall business activity.

In order to obtain the necessary information research conducted are imperative in the highly competitive market environment. The collection of more relevant data about consumers - guests will be catering companies bring in a better position to provide better service and thus contribute to greater satisfaction of the customer. From this it follows that the quality management services and guest satisfaction, based on the knowledge of their expectations. Knowing the desire guest significantly facilitates the activities of catering company, primarily service personnel to fulfill these desires. Here you can talk and the provision of personalized services, which certainly affects the perception of the quality of service to the consumer in a positive way on the one hand, and the separation from the competition, on the other hand.

The expectation of consumers is changing due to numerous factors. If the service provided does not meet all expectations, as a result, the dissatisfaction of the guest. Service quality is largely determined by the ability of the service staff to meet expectations - despite the professional staff and the belief that the quality of services provided, if the customer believes that its needs are not met, the perception of the quality of service will not be favorable to the catering company. In contrast, establishments that fail to meet the needs of consumers, will be perceived as those who provide good, and quality service. Therefore, the quality of service depends on the perception of consumers and therefore it is very important to succeed in meeting the expectations of the guest the process of providing catering services: (Galičić,Ivanovic, 2008)

1. Guest wants made to feel welcome,

2. The guest wants to feel free and

3. The guest wants to enjoy.

The same authors, when it comes to potential guests, give the division into two categories:

1. Guests who care about money and

2. Guests looking for quality. 
Regardless of which profile guest like catering companies should bear in mind that all consumers expect a certain value for their money. This value is reflected in the quality and safety of health products (food or drink), mode of service, the whole experience and so on.

Recognizing profile guest and his desire plays a key role in the market struggle and the impact on the final perception of quality of service by the customer.

Some of the most common expectations of guests restaurants are:

- Fast and accurate service,

- Quality products,

- Affordable price,

- Friendly staff that is capable of responses to special requirements and

- A high level of hygiene .

Consumer satisfaction reflects their expectations, as well as current and previous experiences that have to do with the product or service. The experience, whether it be about the same or a competitive company, affecting expectations and provide a more complete evaluation of the quality of service. In other words, consumers establish internal standards on the basis of which assess the quality of the provided usluge (Bakic, 2010). If there is no previous experience expectations can be formed on the basis of external information under which are considered recommendations to friends, information from the media, marketing activities and others.

Requirements guests today are significantly altered in comparison with the requirements of a decade or further back in time. Significant changes can be attributed to the dynamic lifestyle, dietary changes, economic situation, health-safe aspect, technological innovation, social trends and others.

The most common requirements of modern guests are:

Peace - this involves the location of the restaurant in a quiet environment, pleasant atmosphere in the restaurant and the absence of noise, but also the physical, health and other risks;

Kindness - from service personnel are expected exquisite courtesy, politeness and willingness to meet;

Kitchen - Food is one of the key elements when it comes to the selection of restaurants. Although there are numerous specialized restaurants, guests have the need to consume foods that are not able to prepare themselves to be made of organic foods that do not contain allergens and the like.

Charm - because the hosts more demanding and particular about, they want to experience the excitement at every turn, and at every stage of consumption catering services. Attach great importance to aesthetics, to the interior of the facility and the food they served. In addition, requiring the charm of staff with whom they are in contact; Character - includes features that distinguish the restaurant from others. Thus, the customer wants to stay in the restaurant that meets his expectations and the need - for example. that is luxurious, it is very well thought of, that provides a unique experience and the like; All this falls within the ambit of specific demands of modern consumers who influence the perception of the service provided (Galičić, Ivanovic, 2008).

Levels of customer expectations can be different and conditioned by a number of factors. What is important is their future impact on the formation of internal standards within each individual, based on which evaluates the quality of services. 
Limits to which guests are ready to accept variations quality of service is called the tolerance zone.

If the service level drops below the minimum acceptability, guests will be dissatisfied, or if the level of service out beyond the zone of tolerance and thereby exceeded expectations, the guests will be very pleased and positively surprised. Also, it can be said that the guests do not register the level of quality of service if he is in the zone of tolerance to such an extent as is the case when the level is found at the lower or upper level. Tolerance zone does not have to be the same for all dimensions of quality - depending on the importance of the guest attaches particular dimensions, zone of tolerance may be completely different.

The desire of every catering company is to meet the expectations of guests as much as possible or to be exceeded. In that endeavor, the company should attempt two things:

- To provide personalized service (keeping records of every guest - what has been sending message, what he likes and what not to eat, the previous problems and the like.)

- Do not give too much promise.

How to identify unmet needs and desires of consumers, enterprises resort to marketing research, but that research was as useful for managers of catering establishment, consumer research should be oriented towards collecting the essential information. Certainly that has been providing the highest possible levels of service quality imperative catering companies, but this leads to an increase in their expectations for the next visit).

\section{Consumer satisfaction and his loyalty}

Every company strives towards a goal which is called satisfied customer. It is often the case that in reality consumers are not always, or completely satisfied with the service provided or its quality. This can result in consumers turning to other providers of the same type of services or the formation of loyal users if their needs and desires are met to a greater extent. Customer satisfaction depends on the level of satisfying the needs and desires of consumers or customers in a restaurant. Satisfaction is defined as an opinion arising from the difference between the perception of used services and expectations from it. As factors that largely affect consumer satisfaction, according to perceived quality, awareness of the product or service, value as the ratio of perceived quality and price, previous experience of consumers and others. The quality of the delivered services is not the only determinant that affects consumer satisfaction. Some of the additional determinants are certainly personalized communication and product (service), payment method (eg. A discount for regular customers), unique atmosphere and environment and so on. The aforementioned determinants except that affect satisfaction, it is clear that the causes of discontent and encourage, in turn, enthusiasm service. Certainly it is not possible to fully predict precisely the level of customer satisfaction but should analyze all the influences or factors in order to extract the critical moments in the "delivery" quality and find solutions for its improvement.

Factors causing dissatisfaction in restaurants can be related to unwanted characteristics of the product (cold food, small portions, under-cooked foods, low levels 
of hygiene utensils, etc.), But also to ineffective service processes (impolite staff, long waiting time, mistakenly received orders, incorrect billing, etc.). In the absence of these factors, the satisfaction is most often will not increase, but if they are present, the pleasure will certainly be less. Factors that create a sense of satisfaction among consumers are usually expected characteristics of a product or process. Consumer satisfaction is the main determinant in retaining existing customers on the one hand, and attracting new (potential), on the other hand. Since consumer satisfaction hospitality service provided affects future behavior and choice of services, it can be said that satisfaction is directly related to loyalty to a particular catering establishment. Satisfied customers in the current time bring profit catering company, or to the same consumers maintain and create more profit in the future, pleasure or delight must grow in loyalty.

If satisfaction is not high, the consumer can, despite some satisfaction with the services of a company, decide to also use the services of competing companies. Consumer loyalty and also leads to an increase in the number of new customers or guests the restaurant, which will certainly be the best marketing for the restaurant assuming themselves to be satisfied with the service.

Some of the benefits of having a restaurant of loyal guests are: (Barjaktarović, 2013)

- Retention of existing guest

- The emergence of new guests based on the recommendations of loyal guests

- The continuous inflow of funds,

- Reducing the costs of advertising,

- Establishing partnerships catering facility and guests,

- Benefits in the competition, and

- Planning of operations (procurement, etc.)

Consumer satisfaction depends mainly on the benefits obtained by consuming catering services. In some prestigious restaurants and hotels benefit is not only reflected in the consumption of high-quality prepared foods to be friendly staff quickly delivered, but sometimes only in the presence of such objects brings some benefit to consumers (not uncommon that consumers opt for some restaurants just to to be seen, or to sit next to celebrities).

Such as used for the restaurant, which benefits the guest acquires due to loyalty restaurant are not negligible and are reflected in:

- guest satisfaction because they return,

- Proven quality of food and drinks,

- Providing faster and better services due to the knowledge of the needs and wishes

- Build trust and security

- Acquisition of benefits for loyalty

Due to significant mutual benefits arising from loyalty, restaurants need to work on establishing a long-term stable and even friendly relations with the guests.

Totally satisfaction creates loyal customers, while increasing the level of satisfaction can achieve continuous improvement of quality of service and therefore it is necessary to constantly monitor levels of consumer satisfaction(Kosar, Raseta, 2005).

- The system of complaints and suggestions;

- Monitoring of customer satisfaction through questionnaires or phone calls;

- With the advent of mysterious consumers or guests and 
- By monitoring and analyzing the reasons why some guests stopped to use the services of catering company.

Since customer satisfaction largely conditioned by whether the customer will be loyal to the company, the focus of managers should find quality as a basis that ensures guest satisfaction. Besides the aspects of product quality, special importance in creating satisfaction certainly has helpful staff that is in direct contact with the guests. To its guests satisfied, it is necessary that the employees are happy and motivated to work. No staff among ruled satisfaction during their daily activities, it is not possible to provide quality service and ensure customer satisfaction. If you meet the above conditions, we can expect satisfaction, and due to the existence of continuity and loyalty catering company.

Continuous measurement of customer satisfaction is of great importance for the business of restaurants, since the basis of the results can consider possible shortcomings that affect the level of (dis) satisfaction of the customer and also provide guidance and to cope with competition. The most common tests of guest satisfaction conducted by interviewing guests after gaining experience with the services of a certain restaurant. In addition to the instrument SERVQUAL and DINESERV, restaurants can engage mysterious guests (mystery shoppers) who, after the experience in the restaurant complete the questionnaire and in this way to express satisfaction with the service provided. It is often the case that these specially hired "guests" have special requirements to test and make sure the staff in their professionalism and knowledge. Additional insight into the satisfaction of our guests are appeals, and guest comments. In addition to the book of impressions, modern consumers often share experiences on the internet blogs, social networks or directly on the website of the restaurant, if it is technically enabled. Monitoring these types of reviews of experience in a given competitive or restaurant, provides an excellent basis for directing actions towards improving the quality of services.

\section{Conclusion}

Position organization of the market and competition depends on the competitiveness of products. In order for the product and services were more accessible to the consumer organization-systems will need to look at all aspects. All resources must be mobilized to the efficient and effective implementation of defined vision and goals. The quality and control the production process involved in all segments. The analysis which is made restaurants set new goals. Quality management processes within the organization considered in its entirety and coordinated towards the realization of the universal goal satisfying the consumers fully.

TQM concept in a quality manner allows businesses, regardless of size, to improve production processes, reduce the number of errors, increase performance, in an affirmative way it works on the staff with the aim of competitiveness and profitability.TQM methods and tools effectively show the current status of the organization, monitoring of all parameters, reducing the number of defects, indicating what the problem is and offer concrete solutions for organizations. The use of methods and tools, with real data, represents a powerful tool for troubleshooting and continuous improvement. 
Applying TQM employees active participation in the realization of the production process. Managers define plans and activities with a clear message that without comprehensive application quality no successful organization. Implementation of projects is focused on continuous improvement of quality of service and the joint implementation of managers and employees, because only qualified team has a chance to make a quality product and satisfy consumers.

Serbia is quite late with the application of TQM concepts. Businesses are not competitive, products of lower quality, under-skilled workers, production processes obsolete. Foreign companies investing in our country contribute to our companies and workers to accept a new way of doing business and to make sure that no matter where the organization operating the quality is recognizable everywhere and has the only real value for consumers.

The goal of the company is applying the concept to provide a leading market position, recognition, confidence and satisfaction-dense, with a vision of the future and the constant application of quality improvement. Futur organization is hard to imagine without the full implementation of "Total Quality Menagment", because the quality is recognized and has become a way of life for consumers.

\section{References}

Bakić, O. (2010). Marketing in tourism. Singidunum University, Belgrade.

Barjaktarović, D. (2013). Quality management in the hotel industry, Singidunum University, Belgrade.

Brzaković M Radulovic J, (2014) .Sistemi quality management in educational and scientific institutions - the need and importance, quality and business excellence in education and teaching, Belgrade.

Brzaković M Radulovic J, (2014). Quality management systems in educational and scientific institutions - needs and character, quality and business excellence in education and teaching, Belgrade.

Galičić, V, Ivanovic, In. (2008). Management guest satisfaction. Faculty of Tourism and Hospitality Management, Opatija.

Joseph M. Juran (1988). Juran on Planning for Quality, The Free Press, New York

Kosar, Lj., Raseta, S. (2005). Challenges Quality - Quality management in the hotel industry. Higher hotel management school, Belgrade.

Kotler, F. Keller, K. (2006) .Marketing management, interpreters 12th edition: Lalovic, B., Lucic, M., editors Gligorijevic, M., Bogetić, Z., Belgrade, Data Status, p. 402 ${ }^{\text {nd }}$

Ljubojević, T. (2004). Marketing services. Faculty of service business, Novi Sad.

Popov-Raljić, J. (2013). Sensory analysis of food and beverages. University of Novi Sad, Faculty of Science, Department of Geography, Tourism and Hotel Management, Novi Sad. 
Popov-Raljić, J., Blešić, I. (2012). Food Safety - Implementation of HACCP system in catering and hotel. University of N. Sad, Faculty of Science, Department of Geography, Tourism and Hotel Management, N. Sad.

Hellriegel, D., Slocum, W. (2008). Management, 5th Edition. Addison Wesley Publishing Company, New York. 